DOI: 10.11606/issn.2238-3867.v15i2p231-243

sala preta

ppgac

Dossiê espetáculo: Christiane Jatahy

\title{
A cenografia em questão: entrevista com Marcelo Lipiani e com a participação de Christiane Jatahy
}

\author{
Maria Clara Ferrer
}

Maria Clara Ferrer

Doutora em estudos teatrais/artes cênicas pela Université Sorbonne Nouvelle - Paris 3, onde também leciona.

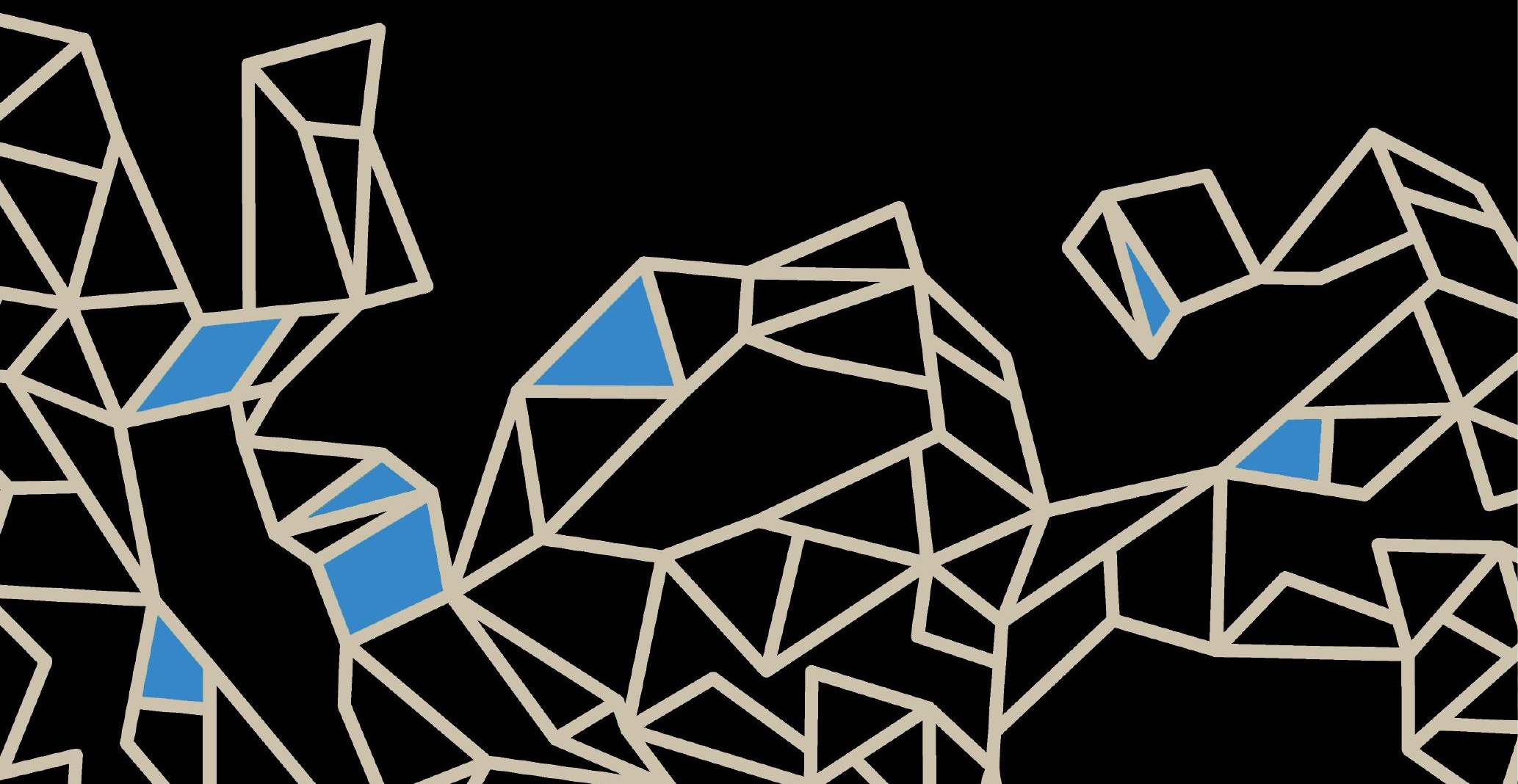




\section{Entre arquitetura, desenho industrial e cenografia}

Marcelo, a cenografia foi a sua primeira formação? Qual é a sua trajetória?

Minha primeira formação é a arquitetura, não pela faculdade que abandonei quase no final, mas pelo estágio e a convivência, de seis anos, que tive com meu primo Hélio Pellegrino, um arquiteto e um artista "compulsivo" que me fez perceber a poesia que a arte e a arquitetura podiam conter. Naquela época, em 1978, estudava fotografia. Quando fiz o vestibular existiam poucas opções: arquitetura, engenharia, medicina, direito ou belas artes. Escolhi arquitetura porque era a única, com alguma cara de "profissão," e que não precisava usar uniformes. Mas, com a chegada da cibernética, achei que iria acontecer, o que de fato está acontecendo hoje, de você bater no computador a área, o norte, o número de quartos, e daí tudo se resolvia (sei que ainda não é bem assim, mas quase lá). Depois me formei em desenho industrial, onde experimentei outros materiais e uma lógica diferente: "Me arrume um problema que a solução pode gerar uma criação". Eu brinco muito com isso. Mas continuo arquitetando bastante, desde 1986, graças a uma cliente de design, que numa consulta sobre um projeto arquitetônico que ela tinha, muito ingênuo acabei voltando e reformando um hotel na serra de Teresópolis. E de lá para cá nunca parei. Acho que a soma dessas experiências é a minha base para a cenografia.

A cenografia começa mesmo na minha vida com a Christiane em 1997, com Peter Pan, fizemos a trilogia nos jardins do Parque Lage: Peter Pan, Alice e Pinóquio (A trilogia da iniciação). E com a Chris sempre foi meio assim, ela já chega com um conceito muito forte e claro, com tudo muito arrumado na cabeça, com uma ideia precisa de aonde ela quer chegar, mas sem ter muita noção de como chegar lá. Ela joga as petecas na minha mão, petecas quase insolúveis, mas acabamos por solucionar todas. Sempre "batemos muita bola" sobre os projetos. A mais "clássica" dela foi no Peter Pan, quando olhando para um lago assoreado por anos de abandono, me disse: "A cena do Capitão Gancho tem que ser aqui, dentro d'água..." Que água? O lago era uma lama... Minha sugestão imediata foi convocar o exército. Acabamos limpando o lago, nós e os 20 adolescentes que formavam o elenco da peça, com muito Lisoforme. Foi lindo, a água corria e a vida e os pássaros voltaram. 


\section{Como o desenho industrial e a arquitetura influenciam o seu trabalho de} cenógrafo? Quais são os princípios que essas outras formações trouxeram para a sua concepção da cenografia?

O desenho industrial tem uma proposta muito interessante de explorar as potencialidades dos diferentes materiais, desde os naturais, minerais até os "ultra-artificiais", plásticos etc. Cada um deles tem a sua especificidade, a sua "onda" e o porquê de estar ali sendo usado.

A arquitetura, com seus conceitos de interno/externo, também influenciou muito o meu trabalho de cenógrafo, tanto que, em quase todos, uso portas, janelas etc. Eu dou bastante importância ao aspecto físico, real, tento buscar o material de verdade. Se o piso é de pedra, tendo a usar pedra. Detesto imitar alguma coisa. Se for para imitar, eu prefiro deixar cru.

O curioso é que a cenografia acabou influenciando meu trabalho de arquiteto. Nessa mistura, passei a pensar a arquitetura não mais necessariamente como uma coisa fixa, que fica ali duzentos anos, e sim, a possibilidade de ser versátil e efêmera, como a vida. Então tem essa troca entre desenho industrial, cenografia e arquitetura.

Nos créditos de E se elas fossem para Moscou?, você é apresentado como cenógrafo e diretor de arte do projeto. $O$ que distingue essas duas funções, ou melhor, o que seria específico a cada uma delas?

No caso de Moscou..., que é uma "peça" e um "filme" simultâneos, elas são intrinsecamente ligadas. A proposta da direção, de uma cenografia no espaço cênico que serve de set para um filme, exibido na sala anexa, traz uma função específica com a qual a cenografia teatral não precisa, necessariamente, se preocupar, apesar de toda a "direção de arte" que a cenografia sempre carrega. A herança fotográfica me provoca essa necessidade estética que acaba virando direção de arte. Quando proponho uma parede estampada para casa das três irmãs ou um trainel/estante no meio da sala delas, além de servir como suporte para todos os objetos necessários para a cena de um "teatro contemporâneo", que dispensa coxias, são questões muito mais fílmicas do que cenográficas. $O$ volume e a profundidade dos planos cinematográficos, proporcionados por esses elementos, ganham força e justificam a proposta cenográfica. Na verdade, está tudo ligado, cenografia e direção de arte. 
A direção de arte é algo relativamente novo na minha vida. Em 2007, a transposição da peça $A$ falta que nos move em filme talvez tenha sido a minha direção de arte mais "original" - projetei, construí a casa onde moramos, e nesses anos também serviu, e ainda serve, de sede da Cia, foi o set único das 13 horas contínuas de filmagem. A direção de arte foi da fundação até o telhado, com todos os recheios: móveis, cores, iluminação etc. A síntese da composição entre arquitetura, design e cenografia.

Eu acho perigoso quando o diretor de arte tem uma mão pesada, quando ele marca demais. Quanto mais despercebida for a minha cenografia meIhor. Para mim, a cenografia está ali para estimular sensações, ajudar a contar a estória, ela é algo transparente, ela está por trás. Não gosto quando a cenografia toma as caras, rouba a cena. Como no teatro é a cenografia que monta a cena, a direção de arte no teatro é algo paralelo, que vai dando a palheta de cor, as texturas, os brilhos, transparências e reflexos, coisas ligadas à arquitetura e ao desenho industrial.

Em Julia acabei arrastando tudo o que foi concebido para a pré-filmagem para a cenografia da encenação. Nessa peça, tudo é muito fragmentado, o ator mexe o painel e o projetor acompanha. As cenas são "entrevistas" através das telas. O que eu gosto é que existe uma imagem que se movimenta no espaço cênico. A cozinha que a gente pré-filmou virou um set de filmagem com veneziana e faixa preta. É tudo muito seco. Às vezes me falam: "Nossa, mas você não vai colocar nem um quadrinho na parede?" Não, para que um quadrinho, um quadrinho de quê? De Paris?! A direção de arte desse set da cozinha era somente isso: dois copos, uma garrafa de vinho, uma tábua, janela, armário e uma mesa de peroba do campo. Não tenho muita preocupação com o elemento de cena, se uso uma bandeja não me importa se ela é bonita ou moderna, mas se o material da bandeja for reflexivo, eu vou usar isso na luz, isso me interessa. As minhas questões estão muito mais ligadas ao resultado que aquela peça traz para a cena, a maneira como ela pode contribuir na cena do que a peça propriamente dita. No espetáculo $A$ falta que nos move, por exemplo, era um jantar com uma mesa na qual devíamos armazenar todos os elementos cênicos, que eram muitos porque os atores cozinhavam durante a peça. Então eu criei uma mesa de metalon e de alumínio completamente desmontável que permitia esse jogo com a luz que refletia no metal. 
No caso de $E$ se elas fossem para Moscou?, como houve separação entre o espetáculo e o filme, como se deu ao longo do processo de criação o diálogo entre a cenografia e a direção de arte?

A direção de arte tinha uma importância muito grande na cenografia porque havia a preocupação com o aspecto bidimensional do filme, então a proposta de trazer uma parede pasteurizada, estampada para preencher o volume, por exemplo, tornava-se necessária. O que já não era o caso em Julia, onde tudo era muito mais seco, liso, mais sóbrio.

Toda parte fotográfica, que é do Paulo Camacho, teve muito diálogo com a cenografia. Fizemos um storyboard do filme todo, com isso havia uma direção de arte mais presente e pré-estabelecida. É bem verdade que os elementos da cenografia como a profundidade da estante, transparência dos vidros e os espelhamentos da luz iam acrescentando aspectos para a fotografia do filme.

\section{DIÁLOGO ENTRE DRAMATURGIA E CENOGRAFIA}

Dentro do processo de criação, em que momento aparece o projeto cenográfico, ele é uma matriz?

Eu poderia dizer que a criação é como um "espirro", você absorve, mescla, faz sinapses, faz ligações, absorve, absorve, absorve e de repente você espirra.

Chris e eu "batemos muita bola" desde o começo de cada projeto, quase todos bem experimentais, vamos acumulando muitas coisas. Eu passo aspectos físicos, e ela vai repensando a proposta dramatúrgica em função disso, até que a gente fecha um conceito, uma forma. Quando os atores chegam já está tudo bem predefinido, ela continua criando em cima e, às vezes, a cenografia acompanha com alterações necessárias. É uma mescla.

Em que medida você considera que a cenografia, essa matriz cenográfica, pode influenciar a dramaturgia in progress?

Julia é um bom exemplo. Para esse espetáculo, a Chris tinha imaginado telas de projeção. Essas telas mostram ao espectador fragmentos dos sets de filmagem que estão atrás delas, onde estarão as cenas ao vivo; além 
disso, existem as imagens pré-filmadas que podem ser mescladas com as imagens ao vivo.

Quando eu trouxe a possibilidade de a tela se movimentar, trazendo sua imagem em movimento, isso ajudou muito na encenação, porque ela conseguiu trazer mais ações para os atores. Tem um jogo muito paralelo.

Em E se elas fossem para Moscou?, quando eu trouxe a proposta dos biombos que se mantinham em pé, na verdade eram tapadeiras que protegem a caixa cênica para que ela não vazasse na imagem filmada; fizemos uma maquete física para estudar todos os movimentos possíveis dentro da configuração cênica.

Quando a forma cênica se estabelece, existe uma releitura da encenação.

O que alimenta sua pesquisa cenográfica? Você se inspira em pinturas, fotografias, modelos arquitetônicos?

É muito caso a caso, eu me focalizo muito na questão dramatúrgica. As experiências vão se acumulando e se contaminando, têm uma influência das criações entre elas, uma palheta que vai se constituindo.

Mas eu não sou exatamente um pesquisador, as coisas acabam se formando mais pela intuição do que pela pesquisa. Na verdade, eu sou mais um Professor Pardal!

Então quais seriam os elementos da sua palheta? Você poderia identificar no trabalho que você faz com a Cia. Vértice elementos ou princípios de cenografia constantes, que ressurgem, propositalmente ou não, entre os diferentes trabalhos?

Parando para pensar, acho que existem desde a trilogia do Parque Lage coisas que vão reaparecendo sim. Entre elas, portas, janelas, espelhos e madeira.

Uma coisa importante é que a arquitetura cênica está deslocada da função caixa cênica, a concepção cenográfica é isolada da caixa; esse aspecto não convencional da utilização do espaço está presente em todos os espetáculos. A Chris sempre tenta tirar o aspecto caixa cênica do palco, e eu sou o seu cúmplice nisso. Eu me divirto com isso. Ter que fazer uma mesinha, uma cadeirinha para um cenário dentro da caixa cênica são coisas que não me apetecem. Eu gosto das encrencas. 
Geralmente, eu entro com luminárias para criar uma luz incidente, independente da luz cênica, que não pareça uma luz teatral. Trago isso tanto em Julia quanto em $E$ se elas fossem para Moscou?

Gosto muito também de objetos concretos, uma poltrona é uma poltrona, uma cadeira é uma cadeira! Por exemplo em Corte seco, que era um espetáculo no qual a Chris brincava com os atores no palco sugerindo a ordem das cenas, eram somente cadeiras e a técnica toda em cena sobre praticáveis, que até hoje utilizamos. Esse tipo de material tipicamente teatral, claramente feito e pensado para a cena, mas que se esconde nas cenografias habituais, é muito presente nas minhas cenografias, gosto da releitura desses objetos ao mostrá-los na cena.

Uma das preocupações que tenho é explorar as diferentes possibilidades que um elemento propõe, não gosto de nada fixo. Outro elemento da palheta, que aparece sempre é o "pivotado", que traz a possibilidade de criar vários pontos de vista e pela sua versatilidade.

Também gosto muito dos formatos retangulares da fotografia, de sair do formato padrão 16:9 do cinema, os fotógrafos ficam loucos comigo. Em Julia usei o 16:6, onde descartávamos 1/3 do quadro fotográfico. Agora em Floresta... estou usando $16: 3$, descarto $2 / 3$. Mas a proporção toma força dramatúrgica na cena. Gosto disso.

\section{Dentro dos seus projetos cenográficos com a Cia. Vértice, como você aborda e projeta a relação com o público nessas formas híbridas entre cinema e teatro?}

Perguntas do tipo "como evitar que o espectador torça o pescoço para ver uma ou outra?" ou "como apresentar as duas linguagens no mesmo 'frame'?" são questões importantes na concepção da cenografia. Tem um lado da cenografia que é a minha arquitetura teatral, tenho muitos estudos sobre todos os pontos de vista possíveis dos espectadores. Eu brigo com as alturas porque os espetáculos têm muitas cenas no chão ou cenas onde a Chris aproxima muito os atores do público e, como nós trabalhamos muito com arquibancadas que são sempre propostas com um desnível de vinte centímetros, isso cria uma visibilidade horrorosa. 
Todas as minhas plantas são muito amplas; tenho a caixa cênica inteira para então começar a fechar o produto. Tenho também a preocupação do tridimensional, de saber como em determinados momentos eu afasto a imagem, e em outros eu a aproximo. Às vezes, a cena pede uma intimidação do público, uma aproximação quase constrangedora, como a cena da mesa em contato direto com a primeira fila da plateia em $E$ se elas fossem para Moscou? Tem esse aspecto que é a arquitetura teatral, e o trabalho em espaços não convencionais me deixa a possibilidade de entrar com uma cenografia dramatúrgica.

\section{O que você chama de cenografia dramatúrgica?}

É um conceito delicado, mas acho que a cenografia deveria ser isso. É difícil fazer que a forma traga uma invenção, uma sensação, que ela ajude a contar algo sobre a estória, que ela provoque alguma coisa no espectador. Esse é o meu carro-chefe. Eu trabalho em cima disso, como é que posso trazer uma sensação, algo emocional a partir da forma, e que tenha, claro, a ver com o texto e a encenação.

Às vezes, em Julia, quando a tela se movimenta, e eu percebo um espectador olhando para cima para entender o mecanismo, fico com a impressão de que a cenografia atrapalha a dramaturgia. Isso não é bom.

Eu gosto de contar um pouco da estória com a cenografia. Eu não consigo decorar uma cena. Tem uma frase, do Tchekhov, eu acho, que diz: "Não ponha uma arma em cena que uma hora ou outra você vai ter que usá-la". O "menos" para mim é muito mais. Eu não consigo colocar um elemento no palco que não tenha função dramatúrgica. A estante, por exemplo, de $E$ se elas fossem para Moscou?, foi algo muito importante porque eu precisava dizer que aquela família ali tinha uma certa cultura, era instruída, daí surgiram os livros, discos, taças e vinhos que são usados na cena.

Com essa proposta de espaços não convencionais, não existe coxia ou a possibilidade de entrar e sair da cena, as coisas já devem estar em cena, então há toda uma ergonomia desses elementos que, de alguma maneira, contam ou ajudam a contar a estória. Existe todo um trabalho que consiste em antever as necessidades e as possibilidades da cena. É um quebra-cabeça 
bem legal. A minha cenografia é muito prática. Simplicidade, elegância, inteligência e ergonomia são os meus parâmetros.

Christiane, gostaria de encerrar a entrevista invertendo o ponto de vista. O Marcelo descreve sua concepção da cenografia como uma cenografia dramatúrgica. Seria pertinente definir o seu trabalho de criação como uma dramaturgia cenográfica?

Sim. Quando eu concebo o meu trabalho a primeira expressão que surge é o aspecto espacial da obra vinculado ao ponto de vista do espectador. $\mathrm{O}$ espaço está intrinsecamente ligado à dramaturgia e à mise-en-scène. Para cada projeto, eu levo para o Marcelo uma ideia inicial pré-estabelecida que vai conceituar a obra e definir o tipo de triangulação com o espectador. Assim começa o nosso diálogo criativo.

Julia é um exemplo bem interessante disso. Explorando a fronteira entre cinema e teatro, eu queria trabalhar com a ideia de desvelamento, de revelação, do teatro que se revela atrás do cinema. Desde o início, imaginei um cenário que se esconde atrás de telas, e que o público pudesse entrever as cenas ao vivo aos poucos, que elas fossem reveladas por brechas que iam surgindo à medida que as telas se moviam. Era importante para mim a relação de voyeurismo do público com as cenas.

Além de dar um formato à ideia, o Marcelo realizou sobretudo uma amarração entre projetores e telas. Ele criou um carrinho de cinema invertido para que cada movimento da tela fosse seguido pelo movimento do projetor. Com isso o cinema ganha uma camada a mais, a imagem se movimenta no espaço e o cinema desliza na frente do espectador.

O Marcelo é um homem da maquinaria, mais do que da tecnologia, ele tem uma criatividade artesanal, ligada aos materiais. De fato, ele não gosta de acentuar o aspecto decorativo do cenário porque o importante é que o espaço esteja intrinsecamente ligado ao conceito da obra. E, ao mesmo tempo, a estética está toda ali na escolha dos materiais, a beleza aparece na sua forma mais simples e necessária.

O que é fundamental para mim é que todo meu trabalho está pautado por uma dramaturgia do olhar. Ponho o espectador como eixo de percepção 
do espaço sem que haja um ponto de vista único, mas múltiplos pontos de vista. Isso é determinante para a construção do espaço cênico.

Outro exemplo significativo é o cubo que criamos para Conjugado. Essa mise-en-scène jogava muito com a fronteira com o real, que é um aspecto muito importante do meu trabalho. O cubo de Conjugado era um apartamento que funcionava de maneira completamente realista. O Marcelo, como arquiteto, criou toda a instalação de água, geladeira, televisão etc. Além disso, eu queria que os espectadores estivessem muito perto do cubo fechado, mas não sabia como fechar o cubo, não sabia muito bem que material utilizar. Então, o Marcelo propôs persianas. Isso veio sublinhar, pôr em negrito a relação de voyeurismo que eu estava buscando.

É interessante que eu fale aqui dessas obras, Julia e Conjugado, porque as duas são inaugurais de trilogias. Conjugado é a primeira peça da trilogia Uma cadeira para a solidão, duas para o diálogo e três para a sociedade, e Julia inaugura uma segunda trilogia. A partir delas, surgiram no nosso trabaIho várias questões ligadas ao espaço determinantes para a relação entre dramaturgia e cenografia que desenvolvemos juntos.

\section{A CENOGRAFIA EM IMAGENS}

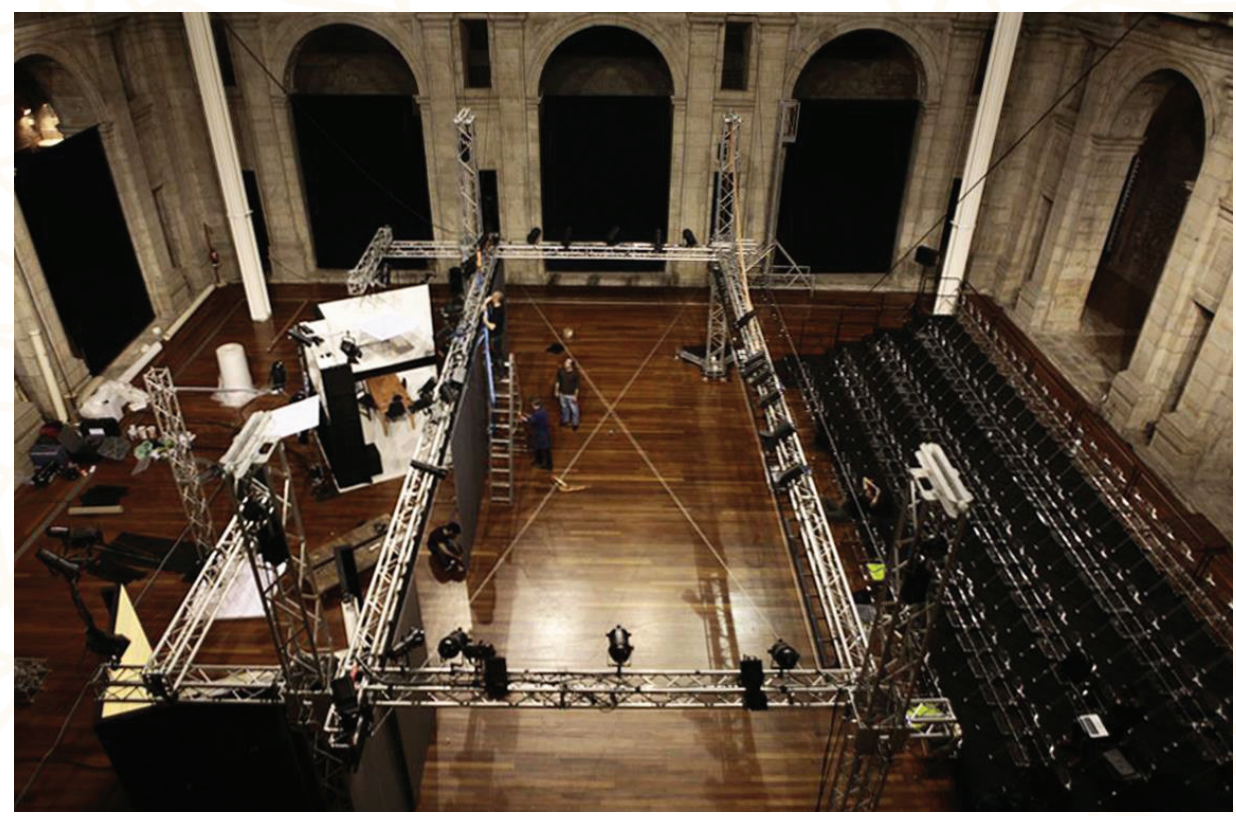

Figura 1 - Julia: montagem em um espaço não convencional, um convento no Porto. 


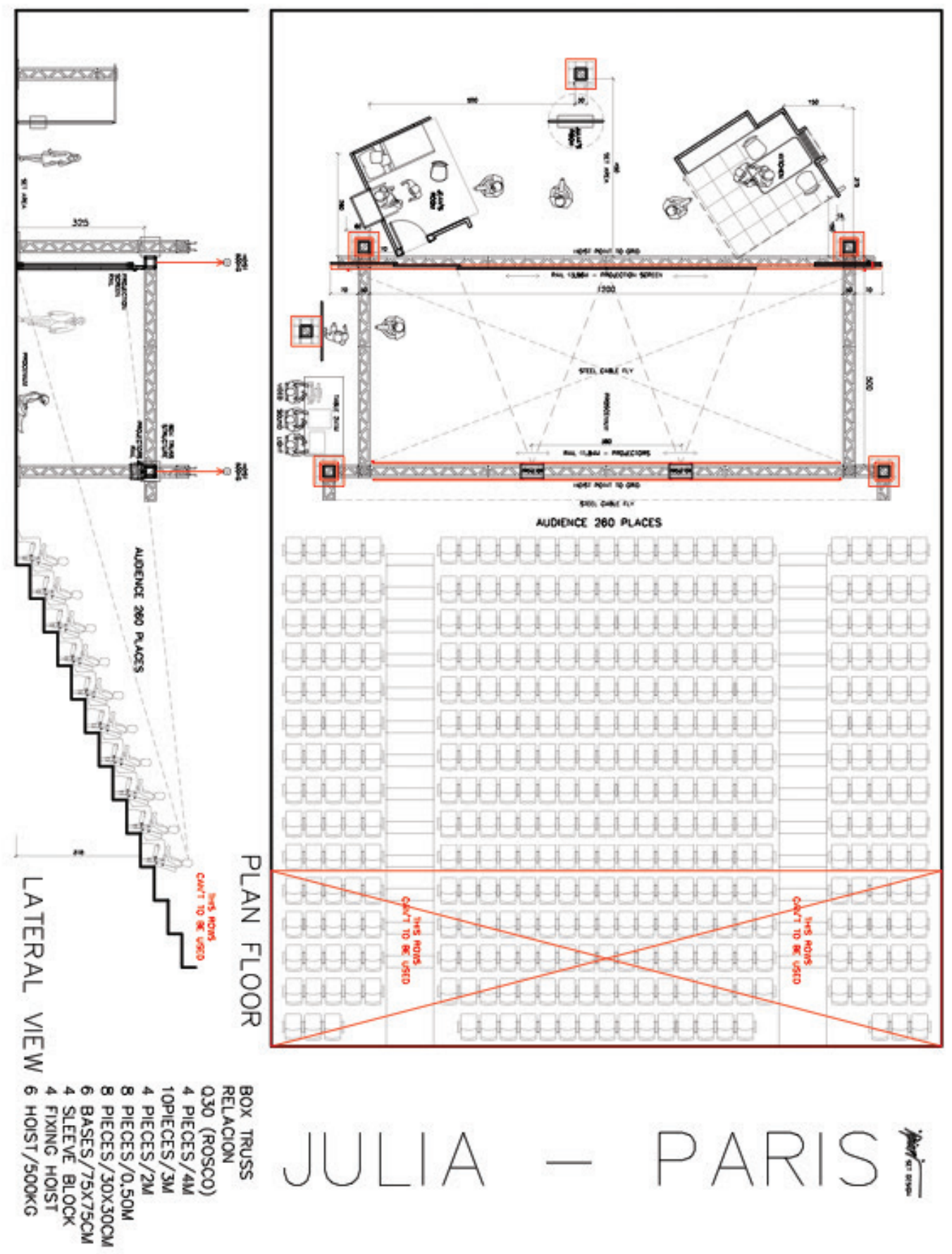

Figura 2 - Julia: plano de sala e de cena para o 104 em Paris. 


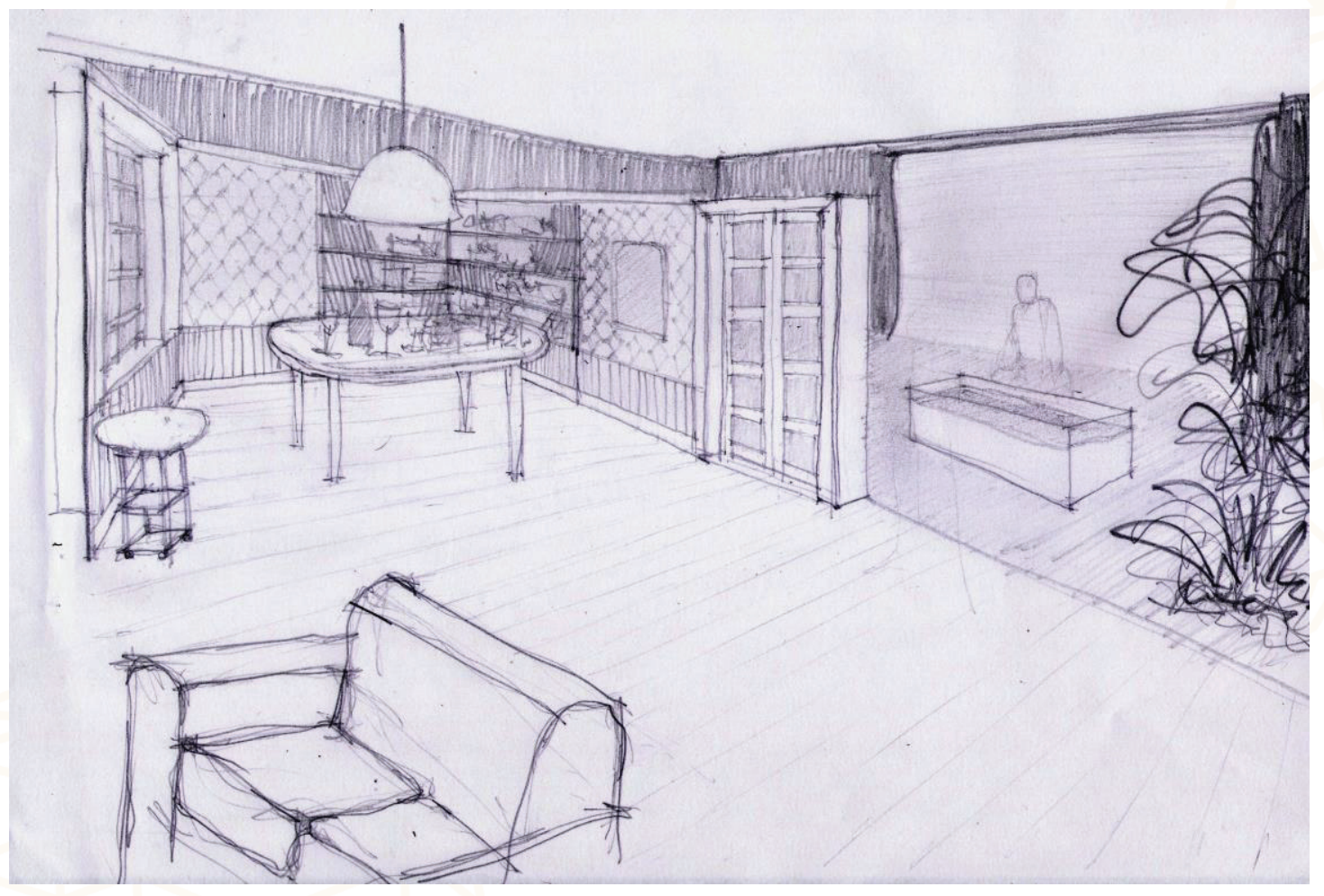

Figura 3 - E se elas fossem para Moscou?, estudo.

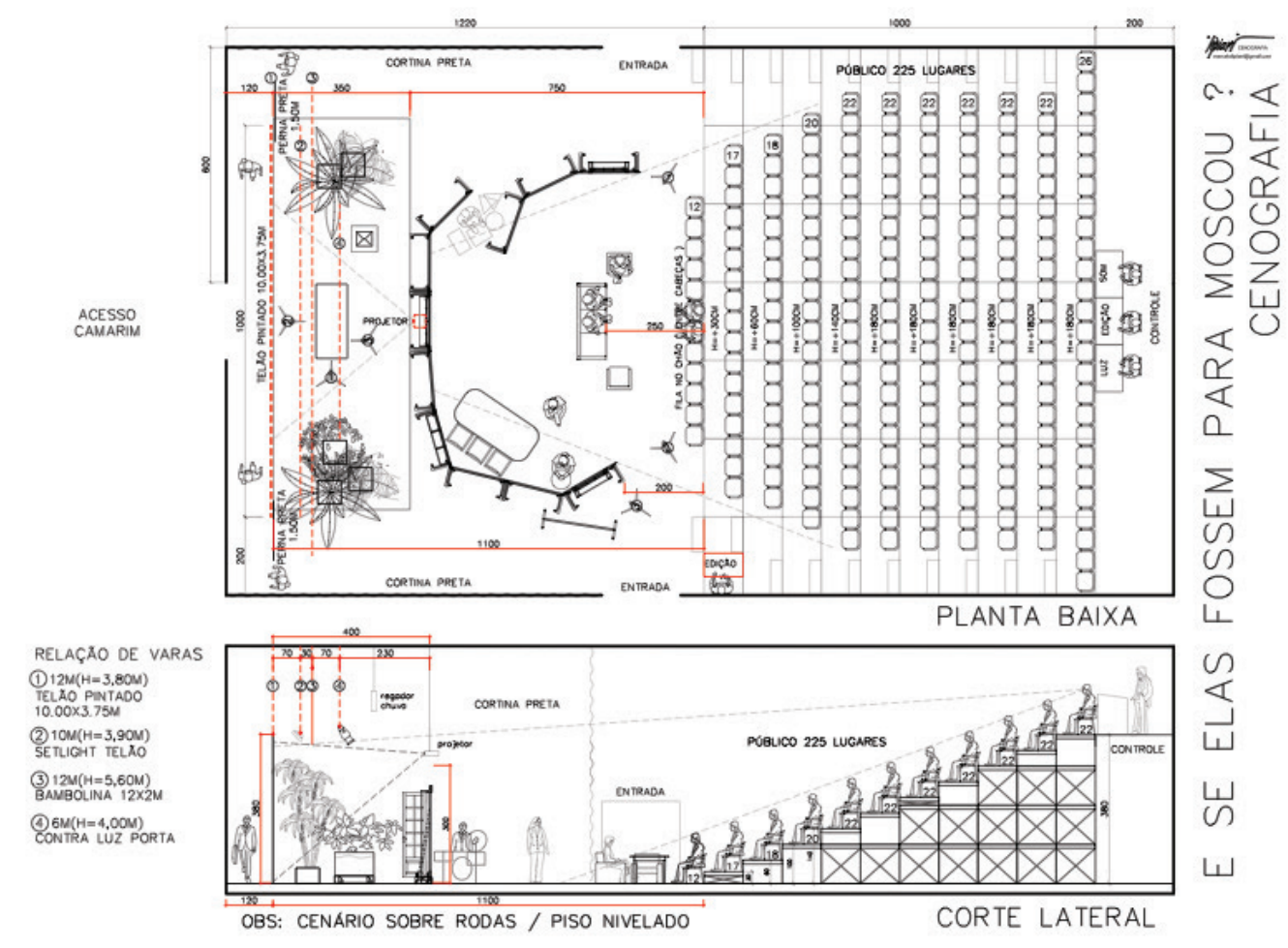

Figura $4-E$ se elas fossem para Moscou?, plano da sala e da cena. 

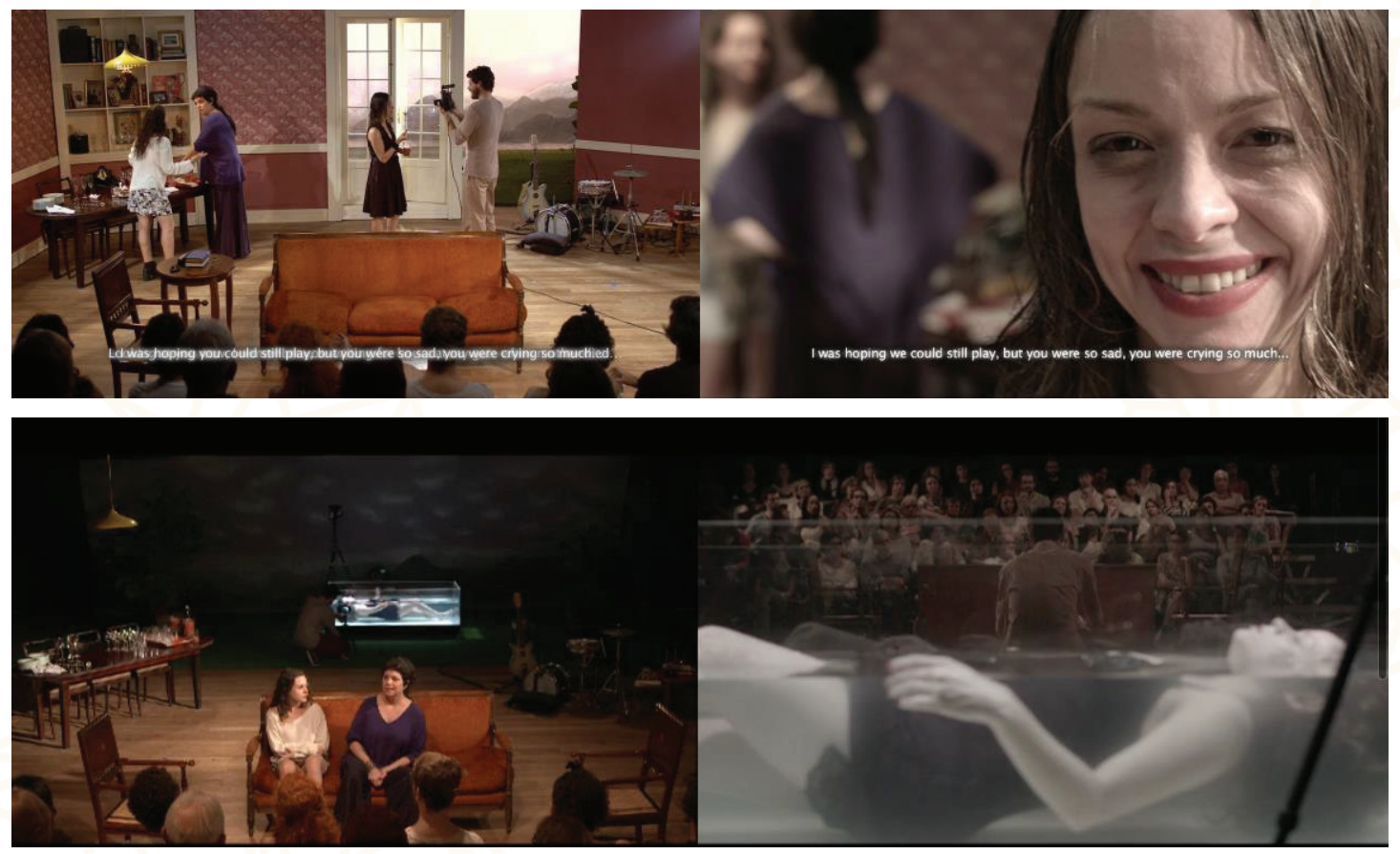

Figuras 5 e 6 - E se elas fossem para Moscou?, simultaneidade espetáculo/filme.

Recebido em 29/10/2015 Aprovado em 29/10/2015 Publicado em 21/12/2015 